\title{
ATP - Bioluminescence as a Technique to Evaluate the Microbiological Quality of Water in Food Industry
}

\author{
Patrícia Dolabela Costa, Nélio José de Andrade*, Frederico José Vieira Passos, Sebastião \\ César Cardoso Brandão and Carolina Gonçalves Freire Rodrigues \\ Departamento de Tecnologia de Alimentos; UFV; 36570-000; Viçosa -MG - Brazil
}

\begin{abstract}
ATP-bioluminescence was used to evaluate the microbiological quality of water samples collected from the water supply, the water treatment system and from a dairy plant, including ammonia-cooling water and industrial water. For industrial water, there was relation between the ATP-bioluminescence technique and microbial count. There were no differences $(p>0.05)$ between water supply and ammonia-cooling water samples for total and free ATP concentrations nor for the microbial counts. Different microbial ATP concentrations were found for these water samples. The results suggested that the physical chemical quality of ammonia cooling water decreased the RLU measurements slightly. It could be concluded that the total ATP concentration was the most effective technique to evaluate the microbiological quality of water used in the food indsutry by ATP-bioluminescence.
\end{abstract}

Key words: Water quality; ATP-bioluminescence measurement; food industry

\section{INTRODUCTION}

Water quality control, for any of the uses in a food plant, is necessary to avoid possible risks to consumers health. In addition, it can reduce negative effects on facilities and processes such as corrosion, deposit and sediment formation and attend the quality criteria of each finished product in the food industry. Water may be used as a component of the final products and as part of the manufacturing process, e.g., transport and cooling. In addition, it is in direct or indirect contact with foodstuff as well as used to wash hands, equipment, utensils and facilities.

Water for human consumption and use in the food industry must be potable and, thus, attend to the standards established by the Brazilian legislation, according to law no. 1469 of the Ministry of
Health of 12/29/2000 in its physical, chemical, microbiological and organoleptical characteristics (Brasil, 2000). Water is generally accepted to be potable when it meets certain established microbiological and physico-chemical requirements. There are about 90 parameters that should be assayed to determine the water quality (Andrade and Macedo, 1996; Brasil 2000; Poretti, 1990). To assess the microbiological quality of water, the conventional microbiological techniques - plate count agar and coliform tests - are laborious and time consuming. To attend the food industries demands, rapid and sensitive methods have been developed to evaluate microbiological quality of several foods and water. These methods are based on microbial growth or metabolism and use principles of ATP-bioluminescence, biophysical, radiometry and impedance measurements. The

\footnotetext{
* Author for correspondence
} 
ATP-bioluminescence is related to the ATP concentration found on the contact surfaces in the food processing systems or in the food samples (Baker el al., 1992; Barrichello and Allil, 1997; Hawronskyj and Holah, 1997; Murphy et al., 1998; Odebretcht et al., 2000; Tydrich, 1996). The ATP detected by this technique is from microbial origin or somatic, vegetal and animal cell origin. There are a number of available commercial equipments utilizing ATP-bioluminescence principles: the ATP reacts with the luciferin-luciferase enzymatic complex and the reaction releases light which intensity can be measured by a luminometer (Biotrace, 2000; Cloquhoun et al., 1998). The higher the ATP concentration on surface or food samples, the higher light intensity released as expressed in the Relative Light Unit (RLU).

The ATP-bioluminescence technique was used in this work to evaluate the water quality of a public water treatment system and in a dairy plant.

\section{MATERIALS AND METHODS}

\section{A) Water samples screening}

Five samples from different steps of a water treatment system were collected, consisting of surface water supply, flocculated, decanted, filtered and chlorinated water. In addition, other four samples were collected in a dairy plant: distilled water, ammonia-cooling water, (from a cooling tower) milk-cooling water (from a milk pasteurization equipment) and industrial water. Three different water samples were selected, based on their physical, chemical and microbiological characteristics to be evaluated by ATPbioluminescence.

\section{B) Physical, chemical and microbiological assays}

The water samples were submitted to the following analyses, as proposed by Greenberg et al. (1992): hardness, mg.l ${ }^{-1}$ of $\mathrm{CaCO}_{3}$; alkalinity, mg. $1^{-1}$ of $\mathrm{NaOH}$; acidity, mg. $1^{-1}$ of $\mathrm{CO}_{2}$; chloride, mg. $1^{-1}$ of $\mathrm{NaCl}$; turbidity, NTU; $\mathrm{pH}$; total plate count (aerobic mesophilic bacteria), CFU.mg. $1^{-1}$ and total coliform, NMP. $100 \mathrm{ml}^{-1}$.

\section{C) Water analysis by ATP-bioluminescence technique}

The water samples previously selected according to A were submitted to the physical, chemical and microbiological analyses (B) and submitted to the
ATP bioluminescence technique by using the Total AQUATEST kit (Biotrace) that determined the free plus microbial ATP, and AQUATEST FREE kit, that determined the free ATP. An aliquot of approximately $0.1 \mathrm{ml}$ was taken from a approximately $50 \mathrm{ml}$ of a water sample in a clean, sterilized $100 \mathrm{ml}$ beaker, by using the kit swabs. The swabs were introduced in a cuvette, containing the luciferin-luciferase enzymatic complex. The ATP present in the water sample reacted with the enzymatic complex and produced a light intensity that was measured by a HILYTEBiotrace luminometer (Biotrace, 2000). The intensity of light formed by the chemical reaction was expressed as Relative Luminescence Unit (RLU). The microbial ATP concentrtation was determined by the difference between total and free ATP.

\section{Statistical Analysis}

To evaluate the microbiological quality of water by ATP-bioluminescence technique, the experiment was conducted applying a randomized complete design with three treatments (water supply, ammonia-cooling water and industrial water samples), six physical and chemical analysis of the water samples (turbidity, $\mathrm{pH}$, acidity, alkalinity, chloride and hardness) and five criteria to evaluate the microbiological quality of the water (free, microbial and total ATP, and aerobic mesophilic bacteria and total coliforms). The experiment was conducted in three trials, resulting in a total of 274 analyses. After the data analysis of variance, the averages of $\log _{10}$ of RLU and $\log _{10}$ of CFU.ml ${ }^{-1}$ or $\log _{10}$ NMP. $100 \mathrm{ml}^{-1}$ were submitted to the Tukey test at $5 \%$ of probability.

\section{RESULTS AND DISCUSSION}

Tables 1 and 2 show the results of the physical, chemical and microbiological analyses of the water samples from the water treatment system and from a dairy plant. There were differences in the analytical results due to the composition of the water. For instance, turbidity varied between 0.6 in the distilled water and 91.5 NTU in the flocculated water. The $\mathrm{pH}$ varied between 6.9 and 8.6 for the industrial water and ammonia-cooling water, respectively. Regarding acidity, variations could be observed from absence in the ammonia-cooling water to $10.4 \mathrm{mg} . \mathrm{l}^{-1}$ in the flocculated water. The 
distilled water presented the lowest content of alkalinity $\left(22.3 \mathrm{mg} . \mathrm{l}^{-1}\right.$ of $\left.\mathrm{CaCO}_{3}\right)$ and the highest was the ammonia-cooling water with $231.7 \mathrm{mg} . \mathrm{l}^{-1}$. In relation to chloride, distilled water showed the lowest level consisting of $9.4 \mathrm{mg} . \mathrm{l}^{-1}$ of $\mathrm{NaCl}$ and ammonia-cooling water the highest level presenting $140.3 \mathrm{mg} . \mathrm{l}^{-1}$. Regarding to hardness, the results showed 18 and $183 \mathrm{mg} . \mathrm{l}^{-1}$ of $\mathrm{CaCO}_{3}$ for the distilled water and ammonia-cooling water, respectively.

In relation to microbiological analysis, there were variations among the water samples assayed. The count of mesophilic aerobic bacteria were 2.70x $10^{0} \mathrm{CFU} \cdot \mathrm{ml}^{-1}$ and $4.40 \times 10^{3} \mathrm{CFU} \cdot \mathrm{ml}^{-1}$ for the industrial water and flocculated water, respectively. The numbers of total coliforms, expressed as MPN. $100 \mathrm{ml}^{-1}$ were as low as $<2$ for the industrial water and as high as $1.10 \times 10^{3}$ for the decanted water.
The physical-chemical and microbiological characteristics of the water supply attended the Brazilian legislation, according to the Resolution $n^{\circ} 20 / 1986$ of the Environmental National Council of the Ministry of Health (Brasil, 1986). Based on the Brazilian legislation, the industrial water presented potable characteristics regarding to the physical chemical and microbiological parameters assayed in this experiment. However, it is important to mention that, currently, approximately 90 parameters might be considered to determine whether a water supply should be treated in a drinking water treatment system, according to the Resolution no. 20/1986 (Brasil, 1986). In addition, the same characteristics are considered to determine the potability of a water sample, according to the Resolution no. 1469/2000 (Brasil, 2000).

Table 1 - Physical and chemical characteristics of the water samples collected from a treatment system and from a dairy plant. Mean of three repetitions

\begin{tabular}{|c|c|c|c|c|c|c|}
\hline \multicolumn{7}{|c|}{ Physical and chemical characteristics } \\
\hline Water Samples & $\begin{array}{c}\text { Turbidity* } \\
\text { (NTU) }\end{array}$ & pH & 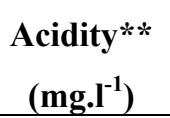 & $\begin{array}{c}\text { Alkalinity*** } \\
\left(\mathrm{mg.l^{-1 }}\right)\end{array}$ & $\begin{array}{c}\text { Chloride }{ }^{* * * *} \\
\left(\mathrm{mg} . \mathrm{l}^{-1}\right)\end{array}$ & $\begin{array}{c}\text { Hardness**** } \\
\left(\mathrm{mg} . \mathrm{l}^{-1}\right)\end{array}$ \\
\hline Water supply & 46.6 & 7.1 & 7.8 & 42.9 & 11.9 & 36.3 \\
\hline Flocculated water & 91.5 & 7.0 & 10.4 & 43.0 & 13.9 & 42.2 \\
\hline Decanted water & 12.5 & 7.1 & 8.8 & 46.3 & 14.9 & 40.7 \\
\hline Filtered water & 0.5 & 7.0 & 7.1 & 42.0 & 17.7 & 39.0 \\
\hline Distilled water & 0.6 & 7.1 & 3.3 & 22.5 & 9.4 & 18.0 \\
\hline Milk-cooling water & 4.4 & 7.0 & 8.0 & 50.5 & 16.2 & 43.2 \\
\hline Industrial water & 1.0 & 6.9 & 7.6 & 33.3 & 14.6 & 41.3 \\
\hline Condensed steam & 3.8 & 7.2 & 7.8 & 23.8 & 13.4 & 20.0 \\
\hline Ammonia-cooling water & 18.6 & 8.6 & 0.0 & 231.7 & 140.3 & 183.0 \\
\hline
\end{tabular}

Samples from water supply, ammonia-cooling water and industrial water were selected according to the their physical, chemical and microbiological characteristics to evaluate the ATPbioluminescence technique. Water supply showed high levels of turbidity and a high number of mesophilic aerobic bacteria and total coliforms. The ammonia-cooling water presented a high value for all the characteristics evaluated. The industrial water was considered as a control due to its good physical, chemical and microbiological characteristics. Table 3 shows the results of the physical and chemical assays of the water supply, ammonia-cooling water and industrial water samples used to compare the ATPbioluminescence technique and conventional microbiological methods for mesophilic aerobic bacteria and total coliforms. The results (Table 3) confirmed the differences in the characteristics previously detected, according to those showed on 
Table 1 . The variance analysis showed significant differences $(\mathrm{p}<0.05)$ among total, free and microbial ATP levels for the different water samples. Also, these differences were observed for mesophilic aerobic bacteria and total coliforms. There were no statistical differences $(\mathrm{p} \geq 0.5)$ by the Tukey test for the water supply and the ammonia cooling water for total, free and microbial ATP concentrations. Similar results were observed for the number of mesophilic aerobic bacteria and total coliforms. The industrial water showed a lower concentration for all the different ATPs assayed and, also, for the microbial counts. Concerning the industrial water, the results showed an agreement between the ATPbioluminescence technique and the microbial method. Both methods classified the water as in a good hygienic condition. According to the manufacturer of the ATP-bioluminescence kit used in this experiment, water samples with a maximum of $150 \mathrm{RLU}\left(\log _{10}<2.18\right)$ are considered in good hygienic conditions. Regardless of the ATP source, the RLU values determined for the industrial water samples were below the manufacturer's specification $(<150$ RLU) and the number of mesophilic aerobic bacteria and total coliform met the standards established by Resolution no. $1469 / \mathrm{MS}\left(<5.0 \times 10^{2} \mathrm{CFU} \cdot \mathrm{ml}^{-1}\right.$ and $\left.<2 \mathrm{NMP} .100 \mathrm{ml}^{1}\right)$. However, the kit does not identify microbial species.

Water supply presented values for total and free ATP concentrations above those obtained for the industrial water. Turbidity and microbial parameters were different for these samples. Comparing the three water samples evaluated, the total and microbial ATP concentrations were higher for the water supply. These URL results are in an agreement with the results obtained for the number of mesophilic aerobic bacteria and total coliform.

Table 2 - Number of mesophilic aerobic bacteria and total coliforms of the water samples collected from a treatment system and in a dairy plant. Mean of three repetitions

\begin{tabular}{l|cc}
\hline \multicolumn{1}{c}{ Water samples } & $\begin{array}{c}\text { Mesophilic aerobic bacteria } \\
\left(\mathbf{C F U} \cdot \mathbf{m l}^{-\mathbf{1}}\right)\end{array}$ & $\begin{array}{c}\text { Total coliforms } \\
\text { MPN.100 }^{-1}\end{array}$ \\
\hline Water supply & $6.5 \times 10^{2}$ & 400 \\
Flocculated water & $1.2 \times 10^{2}$ & 1071 \\
Decanted water & $4.4 \times 10^{3}$ & 110 \\
Filtered water & $1.5 \times 10^{2}$ & 7 \\
Distilled water & $1.70 \times 10^{3}$ & $<2$ \\
Milk-cooling water & $1.5 \times 10^{2}$ & 6 \\
Industrial water & $2.7 \times 10^{0}$ & $<2$ \\
Condensed steam & $3.4 \times 10^{1}$ & $<2$ \\
Ammonia-cooling water & $2.5 \times 10^{3}$ & 90 \\
\hline
\end{tabular}

Table 3 - Physical and chemical analyses of the water samples selected to evaluate ATP-bioluminescence technique. Mean of three repetitions

\begin{tabular}{|c|c|c|c|c|c|c|}
\hline \multirow[t]{2}{*}{ Water samples } & \multicolumn{6}{|c|}{ Physical and chemical analyses } \\
\hline & $\begin{array}{l}\text { Turbidity* } \\
\text { (NTU) }\end{array}$ & pH & $\begin{array}{l}\text { Acidity*** } \\
\left(\text { mg. }^{-1}\right)\end{array}$ & $\begin{array}{l}\text { Alkalinity**** } \\
\left(\mathrm{mg.l}^{-1}\right)\end{array}$ & $\begin{array}{l}\text { Chloride } * * * * \\
\left(\text { mg.l }^{-1}\right)\end{array}$ & $\begin{array}{l}\text { Hardness } * * * \\
\left(\mathrm{mg.l}^{-1}\right)\end{array}$ \\
\hline Water supply & 10.9 & 7.0 & 7.2 & 54.5 & 11.9 & 51.6 \\
\hline Ammonia cooling water & 5.9 & 8.5 & 0.00 & 278.6 & 163.8 & 251.8 \\
\hline Industrial water & 1.0 & 6.7 & 7.4 & 56.5 & 15.3 & 54.7 \\
\hline
\end{tabular}


The results obtained by ATP-bioluminescence technique suggested that water supply was not in a satisfactory hygienic condition, with values above 300 RLU for total ATP, and in warning conditions, between 150 and 300 RLU for free and microbial ATP. The number of total coliforms reached approximately 1000 MPN. $100 \mathrm{ml}^{-1}$. From these results, it could be concluded that the determination of total ATP was the best technique to apply when evaluating the microbial quality of water supply. In this case, the fact that the ATPbioluminescence technique does not differentiate microbial species should not be a problem since the water supply will be submitted to the conventional water treatment, including sedimentation with chemical agents, flocculation, decantation, filtration and disinfection. The used water treatment showed to be efficient to produce water with turbidity and microbiological quality that attends the standard proposed by the Brazilian legislation. The relatively high number of total coliforms determined in the water supply was below the maximum proposed by the legislation (Brasil, 1986)). Thus, the water supply could be used to obtain potable water after adequate treatment. The ammonia-cooling water was selected according to its physical, chemical and microbiological characteristics. This water was considered in alert conditions for total and free ATP concentrations and in good hygienic conditions using ATP bioluminescence technique. Also, in this case, the total ATP concentration was better than the others to evaluate the microbial quality by ATP-bioluminescence. The physicalchemical characteristics have likely been affecting the quantity of the luminescence formed, decreasing the RLU measurement. The ammoniacooling water showed high values of turbidity, $\mathrm{pH}$, alkalinity, chloride and hardness.

Table 4 - $\log _{10}$ of the Relative Luminescence Units (RLU) of the total, free and microbial ATP concentration; $\log _{10}$ of the Colony Forming Unit (CFU) per ml of mesophilic aerobic bacteria and $\log _{10}$ of the More Probable (MPN) of coliforms per $100 \mathrm{ml}$ in the samples of the ammonia-cooling water, industrial water and water supply. Mean of three repetitions

\begin{tabular}{l|r|r|r|r|r}
\hline \multicolumn{1}{c|}{ Water Samples } & $\begin{array}{c}\text { Total ATP } \\
\text { (RLU) }\end{array}$ & $\begin{array}{c}\text { Microbial ATP } \\
\text { (RLU) }\end{array}$ & $\begin{array}{c}\text { Free ATP } \\
\text { (RLU) }\end{array}$ & CFU.ml $^{-1}$ & MPN.100ml $^{-1}$ \\
\hline Ammonia-cooling water & $2.47 \mathrm{a}$ & $1.92 \mathrm{a} \mathrm{b}$ & $2.31 \mathrm{a}$ & $4.23 \mathrm{a}$ & $2.38 \mathrm{a}$ \\
Industrial water & $1.97 \mathrm{~b}$ & $1.22 \mathrm{~b}$ & $1.86 \mathrm{~b}$ & $0.33 \mathrm{~b}$ & $0.30 \mathrm{~b}$ \\
Water supply & $2.69 \mathrm{a}$ & $2.47 \mathrm{a}$ & $2.28 \mathrm{a}$ & $4.09 \mathrm{a}$ & $3.00 \mathrm{a}$ \\
\hline
\end{tabular}

The mean, with same letter, in a same column, did not have a significant difference at $5 \%$ level, by the Tukey test.

The number of mesophilic aerobic bacteria and total coliforms were as high as $1.7 \times 10^{4} \mathrm{CFU} / \mathrm{ml}$ and 242 MPN. $100 \mathrm{ml}^{-1}$, respectively. The results obtained for ammonia-cooling water suggested that a careful analysis of the data obtained by ATP bioluminescence technique was important to evaluate water quality, since RLU measurement could be influenced by the physical and chemical composition of the samples.

Studies have shown that residues of cleaners and sanitizers of common use in the food industry affect the ATP-bioluminescence technique (Green et al., 1998; Green et al., 1999). For instance, the bioluminescence measurements were affected by contact with diluted solutions of six chemical sanitizers. The sodium hipochlorite, quaternary ammonia, peroxide hydrogen $(0.1 \%)$ and triclosan $(0,25 \%)$ sanitizer diluted solutions did not show any significant difference $(\mathrm{p}<0.05)$ in the RLU measurements. However, lactic acid, trisodium phosphate, peroxide hydrogen $(1 \%)$ and triclosan $(0.5 \%)$ decreased the RLU numbers for all the ATP sources. Also, the influence of the chemical sanitizers on the luminescence measurement was observed in another study (Velasquez and Feirtag, 1997). The effect of sodium hypochlorite and a quaternary ammonia compound was evaluated on Escherichia coli O157:H7 suspensions, containing approximately $10^{8} \mathrm{CFU} \cdot \mathrm{ml}^{-1}$.

As compared with the control, residues of $100 \mathrm{mg} .1^{-1}$ of free available chlorine (FAC) increased the RLU values but concentration of 500 and $1000 \mathrm{mg} . \mathrm{l}^{-1}$ of FAC did not modify the bioluminescence measurements. However, residues of 10000 and $50000 \mathrm{mg} . \mathrm{l}^{-1}$ of FAC decreased the RLU values. Diluted solutions of 
quaternary ammonia compound increased the RLU values in approximately $10 \%$. It could be concluded that the total ATP concentration was the most effective technique to evaluate the microbiological quality of water used in the food industry by ATP-bioluminescence.

\section{ACKNOWLEDGEMENTS}

The authors thank the CNPq and FAPEMIG for their financial support to this research.

\section{RESUMO}

A qualidade microbiológica da água do manancial de captação para tratamento na ETA/UFV, da água de resfriamento de amônia e da água industrial de uso em um laticínio foi avaliada pela técnica de ATP-bioluminescência. Nas águas, foram efetuadas, também, as contagens de mesófilos aeróbios, expressos em UFC.mL ${ }^{-1}$ e coliformes totais, expressos em NMP. $100 \mathrm{~mL}^{-1}$. Foi utilizado um luminômetro para os testes de determinação de ATP total e livre, expressos em Unidades Relativas de Luz (URL), nas diversas águas. O ATP microbiano foi determinado pela diferença entre o ATP total e livre. Em relação à água industrial, houve a concordância entre os métodos de bioluminescência e de contagem de mesófilos aeróbios e coliformes totais. As amostras de água de manancial e de resfriamento não apresentaram diferença $(p \geq 0,05)$, pelo teste de Tukey, para as quantidades de ATP total, livre e também para as contagens microbianas. Constataram-se concentrações diferentes de ATP microbiano para essas amostras de água. Os resultados indicam que o teste de ATP total é o mais recomendado para avaliar a qualidade microbiológica da água e sugerem que a qualidade físico-química da mesma pode afetar a formação de luz.

\section{REFERENCES}

Andrade, N. J. and Macedo, J. A. (1996), Higienização na indústria de alimentos. São Paulo : Varela. 182 pp. Baker, J. M.; Griffiths, M. W. and Collins-Thompson, D. L. (1992), Bacterial bioluminescence: applications in food microbiology. J. Food Protect., 55,.62-70.
Barrichello, A. and Allil, M. C. A. (1997), Bioluminescência: uma nova ferramenta para tornar o controle microbiológico mais rápido, fácil e preciso. Rev. Inst. Latic., 52, 71-79.

Biotrace. Biotrace-Xcel (2000), Manual técnico. 140 pp.

Brasil (1986), Resolução CONAMA $n^{\circ} 20$, de 18 de junho de 1986. Classificação das águas doces, salobras e salinas do Território Nacional. Diário Oficial [da República Federativa do Brasil], Seção 1, Brasília, 30 de julho. pp. 11356-11361.

Brasil (2000), Portaria $n^{\circ} 1469$, de 29 de dezembro de 2000. Normas e padrão de potabilidade da água destinada ao consumo humano. Diário Oficial [da República Federativa do Brasil], Brasília.

Colquhoun, K. O.; Timms, S. and Fricker, C. R. A. (1998), Simple method for the comparison of commercially available ATP hygiene-monitoring systems. J. Food Protect., 61, .499-501.

Green, T. A.; Russel, S. M. and Fletcher, D. L. (1998), Effect of chemical sanitizing agents on ATP bioluminescence measurements. J. Food Protect., 61, 1013-1017.

Green, T. A.; Russel, S. M. and Fletcher, D. L. (1999), Effect of chemical cleaning agents and commercial sanitizers on ATP bioluminescence measurements. J. Food Protect., 62, 86-90.

Greenberg, A. E.; Clesceri, L. S. and Eaton, A. D. (1992), Standard Methods for the Examination of Water and Wastewater. $18^{\text {th }}$ ed. American Public Health Association (APHA).

Hawronskyj, J. M. and Holah, J. (1997), ATP universal hygiene monitor. Trends Food Sci. and Technol., 8, 79-84.

Murphy, S. C.; Kozlowski, S. M.; Blander, D. K. and Boor, K. J. (1998), Evaluation of adenosine triphosphate-bioluminescence hygiene monitoring for trouble-shooting fluid milk shelf-life problems. J. Food Sci., 81, 817-820.

Odebrecht, E.; Schmidit, H. J. and Franco, B. G. M. (2000), Avaliação do desempenho de dois equipamentos e um kit que medem a bioluminescência para determinar a eficiência da sanitização de superfícies durante os CIP de uma cervejaria brasileira. In: 17 . Congresso Brasileiro de Ciência e Tecnologia de Alimentos, Fortaleza. Anais... Sociedade Brasileira de Ciência e Tecnologia de Alimentos. pp. 4168.

Poretti, M. (1990), Quality control of water as raw material in food industry. Food Control, 11, 79-83.

Tydrich, L. (1996), New applications for ATP bioluminescence methods. Cereal Foods World, 41, 463-465. 
Velasquez, M. and Feirtag, J. M. (1997), Quenching and enhancement effects of ATP extractants, cleansers, and sanitizers on the detection of the ATP bioluminescence signal. J. Food Protect., 60, 799-803.

Received: June 13, 2002;

Revised: December 26, 2002;

Accepted: August 18, 2003. 